\title{
21
}

\section{The historical archaeology of New Zealand's prehistory}

\author{
Matthew Campbell \\ Anthropology Department, University of Auckland, New Zealand \\ mat.c@cfgheritage.com
}

\section{Introduction}

This paper began life as a review of $A$ Companion to Archaeology (Bintliff 2006), a book intended as a broad overview of the discipline, though largely from a British perspective. The first section is called 'Thinking about archaeology' and contains two contrasting theoretical papers: one by Stephen Shennan ('Analytical archaeology'); and one by Julian Thomas ('The great dark book: archaeology, experience, and interpretation'). The most intriguing thing about reading these papers was that the theoretical concerns of these two British scholars did not seem particularly relevant to the archaeology that I do, and that Atholl Anderson does, the archaeology of New Zealand and the Pacific. We have largely received the theoretical and methodological basis of our archaeology from the Northern Hemisphere but our archaeology is very different from that of the European Neolithic with which Shennan and Thomas are concerned. So while the book hasn't been formally reviewed, it has been put to what I hope is a more interesting use, and one close to the editor's intentions; as a book of ideas, it has set me thinking about the basis of New Zealand archaeology (and Pacific archaeology, though this discussion is largely restricted to New Zealand). This paper doesn't deal with Shennan's and Thomas's ideas and their relevance; rather, it is about what sets our archaeology apart from theirs, because without understanding that it would be fruitless to apply their ideas uncritically.

This understanding of the relationship between imported ideas and New Zealand archaeology is not new; our archaeology is perceived to be different from British or American archaeology and naturally British or American ideas need to be adapted to local circumstances. But what makes the archaeology of neolithic Maori so different from the European Neolithic is not material culture, technology nor subsistence patterns, though clearly these differences are important. The main difference lies in the immediacy of Maori culture. Pre-European archaeology in New Zealand studies part of a living tradition, one that is recorded in great detail in a vast body of ethnography and traditional history. This requires a different approach to archaeological studies of the deep past such as the European Neolithic. 
What I propose is that New Zealand 'prehistoric archaeology' is, in fact, a historical archaeology. This is not true, of course, in the narrowest senses of the term - pre-European Maori did not have writing. It is certain, however, that they had history and, what is more, that that history is accessible to us. When history and archaeology are used to supplement each other the result must be a historical archaeology.

A wide body of documentary sources is available to the New Zealand archaeologist: early European explorer's accounts; the letters, journals and writings of European missionaries and colonists; 19th and 20th century ethnographies; Maori manuscripts recording oral tradition, history and ritual; books, newspapers and other writings by Maori in both Maori and English; Land Court records; the output of Anthropology and Maori Studies Departments from New Zealand's major tertiary institutions; all these and more (including the archaeological record itself) constitute the historiography of the Maori. I refer in this paper to 'tradition' or the 'ethnographic record', which aren't really the same thing, though the ethnographic record contains much that is historical, and tradition much ethnography. This record has a long history of use in scholarship, including archaeology, though past misuse by scholars and archaeologists has led many archaeologists today to distrust it.

\section{Tradition and archaeology in New Zealand}

The early founders of the Polynesian Society turned to tradition in their attempts to formulate a coherent account of the whence of the Maori (most famously Smith 1910, 1913; see Simmons 1976 for a detailed account), which was formalised as the 'Great Fleet tradition'. This taught that Aotearoa (New Zealand) was discovered by Kupe and subsequently settled by the Great Fleet of canoes around AD 1350 (again Simmons 1976 gives a detailed account). Despite misgivings from some scholars (e.g. Golson 1960:397, quoted below), this account was the widely accepted conventional wisdom. Scholarly misgivings were substantiated in 1976 when Simmons published his critical account of the Fleet tradition, showing that much of it was a selective reinterpretation of selected sources (Simmons 1976:315), and, as Clayworth (2001) has subsequently demonstrated, in support of a preconceived theory. As Simmons (1976:321) makes clear, Maori tradition in the 19th century served to validate claims to mana, chieftainship and land for the corporate social groups which existed at that time; 'the social groups who took part in the original settlement no longer exist'. Subsequently, Orbell (1985) showed that the origin traditions were not valid historical accounts at all, though they were valid myths with valid social, political, religious and metaphysical significance.

Until 1976, however, it was still possible for serious scholars to accept the Fleet tradition, and to use methods similar to Smith's. Adkin (1960) formulated a rather fanciful New Zealand prehistory from traditional sources, and Keyes (1960) used tradition to outline the prehistory of D'Urville Island. These two papers provoked a swift response from Golson (1960) in which he demonstrated quite clearly that the origin traditions could not be validated by archaeology, or vice versa. Golson (1960:397-398) said he was 'not necessarily questioning the validity of the Toi and Fleet traditions, but only their usefulness for organising and interpreting the archaeological data of New Zealand prehistory ... the traditions are for these purposes not sufficiently full, precise, or unambiguous, nor do they contain the right sort of information' (emphasis in original). Golson's argument is a critique of the historiography, not the utility of the ethnographic record.

Davidson (1990) later returned to this subject in her submission to the Waitangi Tribunal in the Te Roroa Claim Wai 38 on the place of Maori oral tradition in archaeology. Her specific concern was the expectations that the claimants may have had of archaeology, that it could be used to validate tradition. She concluded that generally archaeology and tradition refer to two very 
different understandings of the past, and neither can be used to validate the other, nor to disprove the other, though local tradition can provide a useful framework for interpreting archaeology.

Golson and Davidson were both responding to specific misunderstandings about the relationship between tradition and archaeology. Neither of them took the next step of outlining what the correct relationship/s might be. Golson, for instance, said our understanding of the culture of the first Maori 'is totally the result of archaeological research' (Golson 1960:386). This is simply not so, as Davidson (1990) makes clear. She noted that archaeology is not the same thing as prehistory, and prehistory draws on a number of disciplines in reconstructing pre-literate society. Archaeology is a set of specific techniques and methods for inquiry into the past; prehistory is a more broadly based discipline that combines and interprets data from several disciplines including archaeology. This distinction breaks down in practice however. Archaeologists are not just technicians whose job it is to generate data for others to use; they are prehistorians (or historical archaeologists) who gather data to interpret it themselves, in conjunction with data and knowledge from other disciplines. So while Davidson (1990) says that 'prehistory may be able to embrace the separate strands of archaeology and oral tradition in a way that archaeology alone cannot', this is precisely the sort of thing archaeologists do every day. The distinction between archaeology and prehistory is conceptually important, but is rarely carried through into everyday practice.

Davidson (1990), in fact, notes that archaeologists frequently draw on the descriptions of the early voyagers to help them understand 18th century Maori society (she refers to 'textaided archaeology'). It is, after all, largely on the basis of their descriptions and collections that the archaeological 'Classic Maori culture' is defined. She then notes that archaeologists fail to appreciate the pitfalls of comparing the culture thus defined with the archaeologically defined 'Archaic' or 'Early Maori culture'. But she then goes on to say that 'Classic Maori culture ... [is] not so different from the earlier East Polynesian culture in New Zealand'.

I find this position ambivalent, an ambivalence that extends throughout New Zealand archaeology. It would be unfair to lay the situation at Golson's and Davidson's feet; their role has been merely to formalise a widely held view, and to incidentally provide me with convenient fodder. I am concerned to show that I am not raising a straw man - he is already there. In this paper, I will show that New Zealand archaeologists use textual sources on a daily basis. As I have outlined, the ethnographic record is a huge body of texts, many of which are historical. I largely agree with Golson's and Davidson's argument; we as archaeologists can't, and shouldn't even try to, prove that such-and-such an ancestor inhabited this pa or that kainga; we ought to merely accept it as true on its own terms. What we can do is critically examine the texts to generate understandings of pre-European Maori society that can help us interpret the archaeological record. This critical examination and analysis of texts lies at the heart of the historical methodology and the claim of any archaeology to be historical.

\section{Archaeology, history and tradition}

Archaeology is a historical science (this alone makes the idea of a separate historical archaeology problematic). The new archaeologists of the 1960s sought law-like regularity in their data (Trigger 1989:373). Historical sciences, on the other hand, recognise patterns in the particular and the contingent. This was one of the major failings of the processual project: choosing the wrong scientific model.

Contingency means that each historical situation is unique in its origins, its circumstances and its outcomes. Contingency obstructs the calculability of history (Kracauer 1969:45). To deal with contingency, history has developed methods for critically evaluating its data. Two 
questions, in particular, the researcher must ask of historical texts: are they credible, and are they reliable (Tosh 1984:51)? As Tosh (1984:58) says, sources are, by nature, 'inaccurate, incomplete or tainted by prejudice and self interest. The procedure is ... to amass as many pieces as possible from a wide ranges of sources.' The historical method proceeds by inferring knowledge from evidence of past events to achieve an analytical, or explanatory, narrative, answering the questions 'why' or 'how'. Sufficient inferences in agreement with each other may be taken to constitute a proof (Lemon 1995).

Other sciences have embraced the historical method, particularly geology and evolutionary biology. The evolutionary biologist Gould (1986:65) claims that proofs are based on iterated pattern ... on types of evidence so numerous and so diverse that no other coordinating interpretation could stand - even though any item, taken separately, could not provide conclusive proof'. Gould maintains that Darwin's unique contribution to science was not so much his theory of evolution, but the establishment of a methodology for deriving such a theory. 'Darwin was, above all, a historical methodologist ... Darwin taught us why history matters and established the methodology for an entire second style of science' (Gould 1986:60). (Of course, this short two-paragraph summary does no justice to the richness of this method.)

This understanding of historical sciences is directly relevant to archaeology. Geertz (1983) pointed out more than 20 years ago that, as the social sciences have retreated from the search for law-like explanations, so they have turned to the arts for appropriate analytical analogies. Rather than making comparisons between social entities and biological organisms or systems, social scientists have made use of metaphors of drama or text. The analogy that post-processual archaeology developed in the mid 1980s was the textual analogy, implicit in the title of Hodder's (1991) seminal post-processual volume Reading the Past (and see also Bintliff 1991; Smith 1992; Patrik 1985). Such an understanding of archaeology implies the written document is just one of several sources of data that must be read together, with the same critical questions asked of them all: are they credible, and are they reliable?

There has been a tendency to generalise the stance that Golson and Davidson took against specific misuses or misunderstandings of tradition in archaeology across the whole relationship between archaeology and tradition. On the contrary, the relationship ought to be a far more positive one. And, in practice, it is. Despite believing at one level that archaeology and tradition don't mix, archaeologists in New Zealand happily mix the two every working day. Even to refer to a site as a pa is to make a value judgement, informed at many levels by the ethnographic record and tradition. The term 'pa' is not functionally neutral; it is an interpretation. We need to accept that this is what we do, to understand how and why we do it, and, more importantly, to adopt and adapt the methods of historical criticism to enable us to do it better. Archaeologists have little problem with integrating the data of physical sciences such as geology, biology or nuclear physics, but not the historical sciences. Perhaps this is because there is little appreciation of the scientific nature of history and how the methods of historical sciences differ from those of physical sciences.

Lightfoot (1995) argues for North America that the understanding of the contact and colonial period must be dependent on the study of prehistory. History is a continuum and European settlers, whether there or here, did not colonise a terra nullius, but a land that already had a history. Artificial divisions of archaeology into history and prehistory disguise continuities (Lightfoot 1995:202). Lightfoot calls for an end to the separation of history and prehistory, with their distinct research agendas, theories and methodologies, which are often kept separate in order to mark out academic territory. The result is that history-making before 1769 (in New Zealand) is no longer permissible. 
This situation has partly come about through 'the erasure of local histories - one of the most cancerous products of international capitalism in both its colonial and metropolitan manifestations' (Schmidt and Patterson 1995:4). History-making (including archaeology), if not in the service of the politics of the day, is nonetheless part of the cultural and intellectual zeitgeist. Thus politically motivated distinctions like 'civilised/modern' versus 'primitive' find their echoes in the separation of historical and prehistoric archaeology. This dualism is as embedded in the discipline of archaeology as it is in the collective Western consciousness.

Overcoming this situation requires that tradition be accepted as a legitimate form of history. Historical archaeology must become more inclusive, and is potentially enriched by newly expanded horizons (Schmidt 2006:3). Schmidt, working with the oral traditions of Africa, calls for oral tradition to be used to supplement the archaeological record without the need a 'test of scientific proof for accuracy'. In other words, they may tell different, but still complementary, stories. Historical archaeology is not located only where tradition and archaeology overlap, but across the combined scope of both. If tradition and archaeology (and linguistics, geology, vegetation history, etc.) seem to contradict each other, then this is the opportunity for the process of history-making to develop a richer, more nuanced and more inclusive account (Schmidt 2006:28). Historians, too, are developing similar conceptual frameworks. Smail (2008:6-11) maintains that 'artifacts, fossils, vegetable remains, phonemes, and various forms of modern DNA ... like written documents, all these traces encode information about the past. Like written documents, they resist an easy reading and must be interpreted with care ... The archeologists, anthropologists, molecular biologists, and neuroscientists who study the deep past are also historians, regardless of the archives they consult.'

\section{Historical archaeology revisited}

Any attempt to rigidly define historical archaeology is bound to fail. Different practitioners of historical archaeology have different ideas of what it is and what its proper subject of study should be. All I can hope to do is outline the historical archaeology I am advocating for New Zealand, but in doing so, I necessarily tap into a wider international debate. Hicks and Beaudry (2006:1) refer merely to 'the archaeology of the period from around AD 1500 up to and including the present', but others are more specific. For Orser (2006:275), historical archaeology is the archaeological study of the 'expansion of Europeans into the non-European world'. For Leone and Potter (1988), it is the archaeology of capitalism. Hall and Silliman (2006) refer to 'the processes that have formed and shaped modernity, and the way the past is understood from the perspective of the present'. Together, these definitions amount to largely the same thing, an archaeology of modern capitalism with its roots in the Renaissance and European colonialism. Colonialism, capitalism and their international impacts are topics worthy of study, but these definitions of historical archaeology are primarily North American concepts (Funari 1999:37; Schmidt 2006:45). They derive from the early, formative work of Deetz (e.g. 1977) and the Annapolis project (e.g. Leone and Potter 1988); the latter, in particular, came to be associated with the study of North American capitalism. Historical archaeology as it is practised in Australasia closely follows the North American model. In Europe, Roman, Mediaeval and post-Mediaeval archaeologies have long depended on written documents. History there is a continuum and the development of post-processual or contextual archaeologies has further broken down the barriers between the disciplines of archaeology, anthropology and history (Funari 1999:40). As in North America, New Zealand lacks Mediaeval castles and the arrival of literate Europeans among the non-literate Maori seems to mark a clear-cut boundary separating prehistory from history. 
Funari (1999:43-47) argues that these definitions rely on the apparently universal nature of modern capitalism, with its origins in European colonialism. Pre-capitalist societies, by contrast, are particularistic and so, then, is their archaeology. But capitalism was not universal; feudal modes of organisation continued well into the 19th century in many parts of Europe and Latin America, and North American plantation slavery is a non-capitalist mode of economic and social organisation. Historical archaeology, as defined above, comes out of a search for a global synthesis, but generalising the North American situation to a global definition fails to recognise that interest continues to lie in the particulars of local contexts (Johnson 1999:35).

A world perspective would not confine historical archaeology to the study of European expansion ... nor to an all-encompassing capitalist system ... and would be concerned with the material culture of literate societies. Special attention would be paid to the relationship between artefacts and written documents in different societies, using texts and archaeological remains as complementary evidence ... as archaeological and documentary sources pose similar and related problems of interpretation ... and as apparent discrepancies between textual and archaeological sources must always be addressed by all scholars concerned with literate societies ... (Funari 1999:57).

It is this type of definition of historic archaeology, one that depends on the interplay of archaeological and written sources, and critically examines and compares all sources, that I am arguing for in New Zealand. The only issue I have with Funari's definition is that it continues to privilege the written word. Pre-European Maori had a sophisticated orality that functioned in many ways analogously to European literacy. Their history may have been of a different kind, but it was, and is, no less authentic. In the 19th century, Maori vigorously adopted writing and recorded their traditional knowledge in a remarkable outpouring (Orbell 1985), the study of which could keep all the university Departments of Maori Studies busy for a very long time to come. Tradition and the ethnographic record in general are valid sources of complementary material for archaeology, though each specific document must individually pass the tests of credibility and reliability.

A truly world perspective on historical archaeology would be concerned with the material culture of all peoples who have an accessible history, and any archaeology that applies the critical method of history to its readings is a historical archaeology.

Archaeology can rarely, if ever, provide a definitive, unfalsifiable proof of the historical record, or vice versa; this sort of validation is not the purpose of historical archaeology, nor a proper use of the ethnographic record. It was because Adkin (1960) attempted to use archaeology this way that Golson (1960) felt compelled to write his rebuttal. It was because of an expectation that it could be used this way that Davidson (1990) provided her submission to the Waitangi Tribunal. Two recent mitigation excavations in New Zealand provide examples (reports in preparation). The Mataraua site near Tauranga is associated in tradition with the Ngai Tamarawaho ancestor Mokoroa (Des Tata pers comm.). The archaeological evidence derived from our excavation would be quite unable to establish the connection between Mokoroa and Mataraua. Similarly, at the UCOL site in Wanganui, we excavated the house of Thomas Bamber, and similarly, the archaeological evidence derived from our excavation would be quite unable to establish the connection between Bamber and the house. In neither case was there anything in the archaeology to show who had lived at these places and we wouldn't expect to find it, though we have no reason to doubt the historical evidence connecting Mokoroa and Bamber to the respective sites. This kind of information comes entirely from non-archaeological sources.

It is the interplay between the two complementary kinds of data, documentary and archaeological, and the analysis of them in tandem that allows us to reach the conclusions we 
do, a historical proof of the kind advocated by Gould (1986:65, quoted above). Knowing, for instance, that Bamber was a blacksmith with his smithy on the adjacent lot allows us to interpret the rubbish pits full of waste iron as connected to his work; waste iron on its own doesn't demonstrate the presence of a blacksmith. The tradition of Mokoroa outlines the place of Mataraua in the local settlement pattern, which archaeology backs up and enlarges on.

At a slightly more complex level, the ethnographic record informs us about more subtle aspects of our archaeology. We know why a pa is a pa and can be quite confident in our judgement, even though that judgement is not a neutral interpretation. But at every stage we have to ask the question of the historical sources: are they credible, and are they reliable? Having established reliability and credibility, the ethnographic record provides a context for the archaeological record. By employing and critically evaluating multiple lines of evidence, the ethnographic record becomes more than just a simple analogue used to directly interpret the archaeology (Lightfoot 1995:205; Kepecs 1997:193). It is not only the ethnographic record that informs archaeology. European forms of history, and historical method, rely on change, development and explanation - they are more than just chronicles. Archaeology provides a time depth to the otherwise timeless record of the 'ethnographic present'.

The ethnographic record was made by chiefs, priests and colonial Europeans who brought their own social and cultural biases to their writings. The evidence of archaeology rarely indicates the predominance of hierarchy and ritual, however. Archaeology can serve as a balance to the biases inherent in the writings. A critical evaluation of the texts in light of who wrote them and why is essential. It must also be taken into account that Maori culture in the 19th century had already been changed by European contact (cf. Feinman 1997:373). A new literacy will have altered Maori attitudes to their own history; the ability to document the past means that a permanent record is created, and the resulting perspectives on the past will differ from those of an oral culture.

\section{Historical archaeology in practice}

Having made the claim that archaeologists use the ethnographic record every day, I need to emphasise that we do not necessarily do so critically. It is this critical analysis that defines historical archaeology. We unreflexively accept that a pa is a pa because we know one when we see one. Perhaps if we critically examined the ethnographic record on pa, including our own archaeological record, we might arrive at a new or expanded understanding of these sites. There are, however, several recent studies that have approached the ethnographic record critically and have produced a much richer and more nuanced account of prehistory.

\section{East Polynesia}

I have until now restricted this discussion to New Zealand archaeology, but some of the better examples of work in this field have taken place in Polynesia. First among these is the work of Kirch and Sahlins at Anahulu (Kirch 1992; Sahlins 1992). Kirch (Kirch 1992:1) describes 'an anthropological experiment that joined archival ethnography with field archaeology, so as to construct an integrated history of Anahulu Valley'. The ethnography derives primarily from the mid 19th century records of the Mahele land reforms. Ambitious in scope, this project has been inspirational to many that have followed it, although in the end, it failed to unite the two strands of ethnography and archaeology into a unified research programme with an integrated outcome.

Kirch and Green (2001) subsequently outlined the elements of an ethnography of an 'Ancestral Polynesian Society'. They used linguistics, archaeology and ethnography (they refer 
to the 'triangulation method') to push the timeframe for this historical archaeology back as far as perhaps $2500 \mathrm{BP}$ (Kirch and Green 2001:1). This exploration of Ancestral Polynesian society has sparked considerable debate, but more importantly, has also acted as a springboard for archaeological and material-culture research, and a model against which new data can be tested. Burley and Shutler (2007), for instance, re-examine the archaeology of Ancestral Polynesian fishing gear from Tonga in light of Kirch and Green's conclusions, resulting in a more refined understanding of Ancestral Polynesian fishing strategies.

These approaches owe much to the historical anthropology in Polynesia of Sahlins (1981, 1985), among others. Kirch and Green (2001:Prologue) trace the rise and fall and rise again of these ideas through the 20th century; the notion that anthropology should not dwell in the timeless ethnographic present, but that its subjects, cultures and methods are products of history.

My own work in Rarotonga, in which I use tradition to contextualise the archaeology of the island, is also strongly influenced by Sahlins (Campbell 2002a, 2002b, 2006). My principal source has been the minute books of the Rarotongan Land Courts. These record the oral testimony of plaintiffs, respondents and witnesses in hearings to decide the ownership of parcels of land - it follows that they are inevitably partial. To make matters worse, any statements they make about prehistory are conditioned by 70 years of missionisation and colonialism. A critical analysis, disentangling the distortions of history and half-truth, is essential if the records are to be read with any confidence. Fortunately the records are sufficiently broad that several witnesses in unconnected cases can tell much the same story and a history of Rarotonga can be reconstructed for the last 200 years or so before European contact. Also, the most interesting and useful information for the archaeologist is usually peripheral to the main purpose of contesting land rights, so that even if the story told in court lacks reliability, the cultural logic behind it does not. The nature of land boundaries, relationships between chiefs and commoners, or conceptions of time and space are all topics that have been covered.

Papamoa

Returning now to New Zealand, the Papamoa dune plain east of Tauranga has been the focus of intensive archaeological mitigation investigation as the city has expanded rapidly along the coast. This previously largely intact archaeological landscape contained, primarily, shell middens with associated cooking features and occasional fish bone, occasional evidence of housing and kumara storage pits, and gardened soils. Swamps behind the foredune would have been an important source of various resources. Radiocarbon dates show this landscape was occupied between AD 1450 and 1750, that is, from the period of initial expansion out of a presumed early occupation around Tauranga harbour (early sites here are not well documented) until just before European contact. The first question is, why was this relatively productive environment abandoned? There is, for instance, no apparent environmental cause; later middens are essentially similar to earlier middens, so there is no immediate evidence of either anthropogenic or natural environmental degradation.

Tradition records that the people who lived at Papamoa were Waitaha a Hei. In the early 18th century, the area was invaded and conquered by Ngaiterangi from Opotiki (Stafford 1967:Chapter 21; Stokes 1980:Chapter 2; Ballara 2003:252). The change in settlement pattern we see with the abandonment of the Papamoa dunes does not have an environmental cause, nor does it reflect evolutionary change in the social structures of Tauranga Maori, the kinds of explanatory factors that traditional settlement archaeology is used to using. Rather, the cause, the Ngaiterangi conquest, is historical and contingent, unpredictable beforehand but clearly 
patterned in retrospect. The exposed and unprotected dune plains became too dangerous to occupy on any permanent basis.

Understanding this, it then becomes possible to ask the next question: what form did abandonment take? Exploitation of the dune plain may have continued, but in a fashion that left much less visible archaeological evidence. It would be difficult to explore this second question without having answered the first.

\section{The Waihou river}

Phillips (2000) examined the settlement archaeology of the Waihou river on the Hauraki Plains. As with my work in Rarotonga, she contextualised the archaeology using traditional accounts, principally from Land Court records. She examined history, landscape, environment, settlement, population and land use for the Waihou, integrating this data with the archaeological evidence. The context she provides is more a physical one than the social context I derived from the Rarotongan records - these records have the potential to provide a wide range of archaeologically useful information that has barely begun to be examined.

\section{Southern Maori}

My final example demonstrates a different approach to using the ethnographic record, but one fully in keeping with the historical archaeology I am advocating. Anderson and Smith (1996; see also Anderson 1998) examine the evidence for sedentary village settlement in southern New Zealand in both the early (14th century AD) and late (18th-early 19th centuries AD) periods. Late-period villages, largely known from ethnographic evidence, arose out of a combination of environmental, economic and political factors that resulted in a very mobile lifestyle with a fixed village base. A scarcity of resources meant that trade between villages was essential, and this trade also underscored the southern Maori polity. In contrast, early villages were characterised by a relative lack of mobility in an environment with very rich, though vulnerable, pockets of resources, in particular seals and moa. These villages were self-sufficient, though they did not outlast the depression or extirpation of local prey. Anderson and Smith have contrasted the archaeological and ethnographic records of either end of the span of human occupation in southern New Zealand to find complementary explanations for superficially similar settlement patterns.

\section{Conclusion}

I have proposed that the proper subject of historical archaeology is the archaeology of peoples with an accessible history, and that its appropriate core methodology is the critical methodology of history. It is the methodology, rather than any specific subject, that is crucial here.

Some of the arguments put forward for accepting the ethnographic record as credible and reliable might seem more political than scientific (for instance, the quote from Schmidt and Patterson, above). It is a post-modern truism that science is inevitably politicised, and this is particularly true for archaeology (Wylie 1992; Shanks 2006). It is, however, possible to put forward the simplest test for the usefulness of the ethnographic record in New Zealand archaeology. The strictly scientific approach would be to put forward the null hypothesis that 'the ethnographic record has nothing to contribute to archaeology'. I prefer to rephrase this as a simple question: 'Does the ethnographic record have a contribution to make?' The answer, as I think I have shown, is 'yes', in which case the methodology I have advocated here becomes essential. 


\section{Acknowledgements}

This paper is offered to Atholl in acknowledgement of many years of friendship, teaching and inspiration. Janet Davidson and Ian Smith were kind enough to comment on an earlier version of this paper. Peter Clayworth provided an electronic copy of his thesis.

\section{References}

Adkin, G.L. 1960. An adequate cultural nomenclature for the New Zealand area. Journal of the Polynesian Society 69:228-238.

Anderson, A.J. 1998. The Welcome of Strangers: An Ethnohistory of Southern Maori A.D. 1650-1850. Dunedin: University of Otago Press.

Anderson, A.J. and I.W.G. Smith 1996. The transient village in Southern New Zealand. World Archaeology 27(3):359-371.

Ballara, A. 2003. Taua: 'Musket Wars', 'Land Wars' or Tikanga? Warfare in Maori Society in the Early Nineteenth Century. Auckland: Penguin.

Bintliff, J. 1991. The Contribution of the Annaliste/Structural History Approach to Archaeology. In J. Bintliff (ed), The Annales School and Archaeology, pp. 1-33. Leicester University Press, Leicester.

Bintliff, J. (ed) 2006. A Companion to Archaeology. Blackwell, Malden MA.

Burley, D.V. and R. Shutler, Jr. 2007. Ancestral Polynesian fishing gear: archaeological insights from Tonga. In A. Anderson, K. Green and B.F. Leach (eds), Vastly Ingenious: The Archaeology of Pacific Material Culture, in honour of Janet M. Davidson, pp. 155-172. Dunedin: Otago University Press.

Campbell, M. 2002a. Ritual landscape in late pre-contact Rarotonga: a brief reading. Journal of the Polynesian Society 111(2):147-170.

Campbell, M. 2002b. History in prehistory: the oral traditions of the Rarotongan Land Court records. Journal of Pacific History 37(2):221-238.

Campbell, M. 2006. Memory and monumentality in the Rarotongan landscape. Antiquity 80:102-117.

Clayworth, P. 2001. An indolent and chilly folk: the development of the idea of the 'Moriori myth'. Unpublished $\mathrm{PhD}$ thesis, University of Otago.

Davidson, J.M. 1990. Maori archaeological traditions and archaeology. Unpublished report to the Crown Law Office, Wellington (Wai-38, Document \#H6).

Deetz, J. 1977. In Small Things Forgotten: The Archaeology of Early American Life. Garden City: Anchor Press/Doubleday.

Feinman, G.M. 1997. Thoughts on new approaches to combining the archaeological and historical records. Journal of Archaeological Method and Theory 4(3/4):367-377.

Funari, P.P.A. 1999. Historical archaeology from a world perspective. In P.P.A. Funari, M. Hall and S. Jones (eds), Historical Archaeology: Back from the Edge, pp. 37-66. London: Routledge.

Geertz, C. 1983. Blurred genres: the reconfiguration of social thought. In C. Geertz (ed), Local Knowledge: Further Essays in Interpretive Anthropology, pp. 19-35. New York: Basic Books.

Golson, J. 1960. Archaeology, tradition, and myth in New Zealand prehistory. Journal of the Polynesian Society 69:380-402.

Gould, S.J. 1986. Evolution and the triumph of homology, or why history matters. American Scientist 74(1):60-69.

Hall, M. and S.W. Silliman 2006. Introduction: archaeology of the modern world. In M. Hall and S.W. Silliman (eds), Historical Archaeology, pp. 1-19. Malden: Blackwell.

Hicks, D. and M.C. Beaudry 2006. Introduction: the place of historical archaeology. In D. Hicks and M.C. Beaudry (eds), The Cambridge Companion to Historical Archaeology, pp. 1-9. Cambridge: Cambridge University Press. 
Hodder, I. 1991. Reading the Past: Current Approaches to Interpretation in Archaeology. Cambridge: Cambridge University Press.

Johnson, M. 1999. Rethinking historical archaeology. In P.P.A. Funari, M. Hall and S. Jones (eds) Historical Archaeology: Back from the Edge, pp. 23-36. London: Routledge.

Kepecs, S. 1997. Introduction to new approaches to combining the archaeological and historical records. Journal of Archaeological Method and Theory 4(3/4):193-198.

Keyes, I.W. 1960. The cultural succession and ethnographic features of D'Urville Island. Journal of the Polynesian Society 69:239-265.

Kirch, P.V. 1992. The Archaeology of History. In P.V. Kirch and M.D. Sahlins (eds), Anabulu: The Anthropology of History in the Kingdom of Hawaii, Volume 2. Chicago: The University of Chicago Press.

Kirch, P.V. and R.C. Green 2001. Hawaiki, Ancestral Polynesia: An Essay in Historical Anthropology. Cambridge: Cambridge University Press.

Kracauer, S. 1969. History: The Last Things Before the Last. New York: Oxford University Press.

Lemon, M.C. 1995. The Discipline of History and the History of Thought. London: Routledge.

Leone, M. and P. Potter 1988. Introduction: issues in historical archaeology. In M. Leone and P. Potter (eds), The Recovery of Meaning, 1-22. Washington: Smithsonian Institution Press.

Lightfoot, K.G. 1995. Culture contact studies: redefining the relationship between prehistoric and historical archaeology. American Antiquity 60(2):199-217.

Orbell, M. 1985. Hawaiki: A New Approach to Maori Tradition. Christchurch: The University of Canterbury.

Orser, C.E. 2006. The archaeologies of recent history: historical, post-medieval, and modern-world. In J. Bintliff (ed), A Companion to Archaeology, pp. 272-290. Malden: Blackwell.

Patrik, L.E. 1985. Is there an archaeological record? In M.B. Schiffer (ed), Advances in Archaeological Method and Theory, pp. 27-62. Orlando: Academic Press.

Phillips, C. 2000. Waihou Journeys: The Archaeology of 400 Years of Maori Settlement. Auckland: Auckland University Press.

Sahlins, M.D. 1981. Historical Metaphors and Mythical Realities: Structure in the Early History of the Sandwich Island Kingdom. Ann Arbour: The University of Michigan Press.

Sahlins, M.D. 1985. Islands of History. Chicago: The University of Chicago Press.

Sahlins, M.D. 1992. Historical Ethnography. In P.V. Kirch and M. Sahlins (eds), Anahulu: The Anthropology of History in the Kingdom of Hawaii, Volume 1. Chicago: The University of Chicago Press.

Schmidt, P.R. 2006. Historical Archaeology in Africa: Representation, Social Memory, and Oral Traditions. Lanham: AltaMira Press.

Schmidt, P.R. and T.C. Patterson 1995. Introduction: from constructing to making alternative histories. In P.R. Schmidt and T.C. Patterson (eds), Making Alternative Histories: The Practice of Archaeology and History in Non-Western Settings, pp. 1-24. Sante Fe: School of American Research Press.

Shanks, M. 2006. Archaeology and politics. In J. Bintliff (ed), A Companion to Archaeology, pp. 490-508. Malden: Blackwell.

Shennan, S. 2006. Analytical archaeology. In J. Bintliff (ed), A Companion to Archaeology, pp. 1-20. Malden: Blackwell.

Simmons, D.R. 1976. The Great New Zealand Myth: A Study of the Discovery and Origin Traditions of the Maori. Wellington: A.H. and A.W. Reed.

Smail, D.L. 2008. On Deep History and the Brain. Berkeley: University of California Press.

Smith, C.D. 1992. The Annales for Archaeology? Antiquity 66:539-542.

Smith, S.P. 1910. History and Traditions of the Maoris of the West Coast, North Island of New Zealand prior to 1840. New Plymouth: T. Avery. 
Smith, S.P. 1913. The Lore of the Whare-wananga, or, Teachings of the Maori College on Religion,

Cosmogony, and History: Written down by H.T. Whatahoro from the Teachings of Te Matorohanga and Nepia Pohuhu, Priest of the Whare-wananga of the East Coast, New Zealand. New Plymouth:

T. Avery.

Stafford, D.M. 1967. Te Arawa: A History of the Arawa People. Wellington: A.H. and A.W. Reed.

Stokes, E. 1980. A History of Tauranga County. Palmerston North: Dunmore Press.

Thomas, J. 2006. The great dark book: archaeology, experience, and interpretation. In J. Bintliff (ed), A Companion to Archaeology, pp. 21-36. Malden: Blackwell.

Tosh, J. 1984. The Pursuit of History: Aims, Methods and New Directions in the Study of Modern History. London: Longman.

Trigger, B.G. 1989. A History of Archeological Thought. Cambridge: Cambridge University Press.

Wylie, A. 1992. The interplay of evidential constraints and political interests: recent archaeological research on gender. American Antiquity 57(1):15-35. 